\title{
How Housing Booms Unwind: Income Effects, Wealth Effects, and Feedbacks through Financial Markets
}

\author{
KARL E. CASE* \& JOHN M. QUIGLEY** \\ *Wellesley College, USA \\ ${ }^{* *}$ University of California, Berkeley, USA
}

\begin{abstract}
This paper considers dynamics in the reversal of booms in the housing market. We analyze three related mechanisms which govern the propagation of changes in the housing market throughout the rest of an advanced economy: wealth effects, income effects, and effects through financial markets. As the decade-long boom in the US housing market unwinds, we anticipate that there will be small wealth effects transmitted to the economy, but there will be large income effects affecting the rest of the economy and substantial financial market effects. If the current decline in housing starts and residential investment echoes the declines of the last three housing downturns, we estimate that gross national product (GNP) growth will be reduced by close to 3 per cent. Beyond the decline in housing investment, the recent turmoil in financial markets makes a recession induced by housing market conditions increasingly likely.
\end{abstract}

KEY WORDS: Housing cycles, residential investment, recession

\section{Introduction}

Property markets have always been cyclical, and economists on both sides of the Atlantic have explored the causes and consequences of cyclicality in housing and commercial real estate. Indeed, for more than a half century after the great depression, the National Bureau of Economic Research (NBER) regularly explored linkages among real estate investment, mortgage credit, and aggregate business cycles (see, for example, NBER volumes by Wickens \& Foster, 1937; Blank, 1954; Abramovitz, 1964; Zarnowitz, 1992). During 2006 and 2007, the US housing market turned rapidly from a boom of historic proportions measured either by prices, sales volumes, or new production, to a period of decline. The extent and character of this reversal will have important consequences for the American economy, and many of these effects will be transmitted elsewhere. The extent of the reversal will determine the number of job losses and their distribution, the extent to which national income and aggregate

Correspondence Address: Karl E. Case, Department of Economics, Wellesley College, 106 Central Street, Wellesley, MA 02481, USA. Email: kcase@wellesley.edu

ISSN 1461-6718 Print/1473-3629 Online 08/020161-20 (C) 2008 Taylor \& Francis

DOI: $10.1080 / 14616710802037383$ 
output will fall (or grow more slowly), and the ultimate impact on financial institutions such as banks, mortgage lenders, the government-sponsored enterprises (GSEs), and investment firms.

Housing market declines will also have significant effects on household and firm balance sheets. For the better part of three decades, the value of residential real estate, including land and capital, has gone up dramatically. Between 2000 and 2005, US households added $\$ 10$ trillion in assets to their balance sheets, most of it due to increases in the value of land. This boom in construction and land value was supported by unprecedented liquidity in financial markets and a substantial increase in the availability of mortgage credit.

In this paper we analyze the way that booms in housing cycles end. We consider three related mechanisms: wealth effects, income effects and financial market effects.

First, we explore what we know about wealth effects. When households' asset values increase, households can be expected to spend more than they otherwise would have, either by withdrawing equity from assets or by saving less in other forms. Similarly, when households' asset values fall, this may lead to a contraction in consumer spending. A growing literature documents the effects of home price appreciation and depreciation on personal expenditures and savings behavior.

Second, we evaluate income effects. When existing home sales decline or housing starts drop, the economy experiences a decline in aggregate expenditure and ultimately a reduction in income and employment. This occurs through several distinct channels. Fewer sales of existing homes means that brokers, building inspectors, appraisers, mortgage lenders, home appliance firms, and others in the real estate industry face a decline in demand and experience a direct loss of income. While the sale of an existing dwelling unit is simply a transfer or an exchange of assets (and thus is not a component of national income), the fees and induced expenditures associated with the exchange are high; the transfer typically induces spending on furniture, appliances, decorating, and so forth, as well as fee income from the services provided by brokers, lenders, appraisers, and others.

Without doubt, the biggest direct effect is likely to result from the decline in new housing construction. The construction industry in the US employs 7.5 million workers, and in the beginning of 2006 new investment in residential structures was at an annual rate of over $\$ 800$ billion dollars, or over 5.5 per cent of nominal gross domestic product (GDP) (see US Department of Commerce, Bureau of Economic Analysis, NIPA Accounts). By October 2006, housing starts had fallen to an annual rate of 1.49 million from a peak of 2.27 in January of the same year (US Census Bureau, Construction Reports). By March 2008 housing starts fell below one million to 947,000, and this has already had a dampening effect on GDP growth.

Finally, much of what happens in the next few years will be determined by the substantial financial market effects already causing major disruptions in fixed income markets across the globe. US mortgage markets have expanded and changed in character dramatically over the last dozen years. There was - until very 
recently - massive liquidity, a large increase in the sub-prime mortgage market, a dramatic shift from traditional fixed-income mortgages to more complex and often exotic instruments, and complex risk-sharing arrangements among GSEs, mortgage insurers, Wall Street firms, and world capital markets. Until now, this new credit environment has never been tested in a volatile real estate market. The magnitude of these financial effects will depend to a large extent on the depth of the decline in home prices and the consequent increase in mortgage defaults. With the collapse of the sub-prime mortgage-backed securities market, the financial market effects loom large as firms struggle with non-liquid portions of the mortgage market, non-performing loans and portfolios - and a lot of bad debt.

\section{Wealth Effects}

Between 2000 and 2005, a period of low inflation, the total value of the residential real estate in the US increased by $\$ 10$ trillion, from roughly $\$ 15$ trillion to $\$ 25$ trillion. In contrast, total financial wealth held by US households oscillated. Nevertheless, it was about $\$ 40$ trillion in 2000 and 2005 (see Case, 2007). The bulk of the increase in home values was on the west coast and in the north east. Seven states account for 47 per cent of the total real estate value and a larger per cent of land value in the US (Case, 2007). Housing wealth has grown enormously over the past decade, especially on the coasts.

It has been widely observed that changes in stock prices are associated with changes in aggregate consumption. In statistical models relating changes in log consumption to changes in log stock market wealth, the estimated relationship is generally positive and economically meaningful. Under a standard interpretation of these results, from a suitably specified regression, the coefficient measures the 'wealth effect' the causal effect of exogenous changes in financial wealth upon consumption behavior.

There is good reason to expect that changes in housing wealth exert effects upon household behavior that are quite analogous to those found for stock market wealth (but see Muellbauer, 2007, for an extensive discussion). Until recently, however, there was little comparative research on this issue. One might expect the housing wealth effect to have become more important in recent decades, as institutional innovations (such as second mortgages in the form of secured lines of credit) have made it as simple to extract cash from housing equity as it is to sell shares or to borrow on margin.

In recent research using annual data for OECD countries during 1975-2000 and quarterly data for US states during the 1982-1999 period, Case et al. (2005) reported a large and statistically significant relationship between log housing wealth and log consumption. The estimated elasticity based upon US states, 0.034-0.054, suggests that a 10 per cent change in housing wealth is associated with a 0.3 to 0.5 per cent change in aggregate consumption (see Case et al., 2005, Tables 3 and 4). This suggests that the buoyancy of the housing market after the turndown in world stock markets in 2000-2003 helped avert a recession in the developed world. 
Does this mean that the slowdown in the housing market observed since 2006 will be manifest as a direct reduction in consumer spending through this wealth effect - as lower house prices reflect reduced wealth and lead to lower levels of consumption? Probably not.

There are two reasons why the current slowdown in the housing market by itself is not likely to lead directly to significantly reduced household consumption through the wealth effect (although if the combined effects of all the factors discussed here lead to a recession, that would, of course, lead to a drop in consumer spending).

In the first place, the analysis based upon US states also provides clear evidence of an asymmetric response of consumption to changes in housing wealth. Case et al. (2005) report the results of a variety of statistical models which distinguish between the consumption response to increases in housing wealth and the consumption responses to decreases in wealth (see Appendix Table 3). In these statistical models, the estimated effect of a 10 per cent increase in housing wealth upon consumption is large and highly significant, increasing consumption by 0.6 to 1.1 per cent. But the estimated effect of decreases in household wealth upon consumption is uniformly small and is insignificantly different from zero in all specifications. To be sure, the estimated effects of decreases in wealth are not precisely estimated (Muellbauer (2007) provides some careful robustness checks on these estimates). Nevertheless, these results do suggest that reductions in housing prices and housing wealth would not lead to significant reductions in household consumption.

But there is a second and even more important reason to expect that the wealth effects from the current downturn in the housing market will be negligible. This arises from the price-equilibrating process in the housing market - namely the downward stickiness of prices.

Every housing downturn, national or regional, begins with an excess supply of available dwellings, in most cases because demand has declined. Often downturns in the housing market are precipitated by rising interest rates, but demand can drop for other reasons as well: demographic pressures, a decline in the core economy with falling income or rising unemployment, or a change in market psychology. There are also clear instances where housing production simply gluts the market by increasing faster than household formation. Of course, more than one of these causal factors may be present, and several factors may interact. A decline in a regional economy, or simply a glut of condominiums, can lead to a marked increase in the number of listings, newspaper articles, and 'For Sale' signs. This, in turn, can trigger a shift in consumer psychology accelerating a demand decline.

In all cases, the market-clearing process follows a common pattern. Since housing is heterogeneous, and 'comparable' sales are not sales of identical units, sellers are uncertain of the actual worth of their properties. Indeed, the value of any dwelling is determined in a stochastic process in which buyers and sellers search for exchange terms that will lead to a sale. In most instances, the initial asking or offering price is set high for understandable reasons (see Case, 1986). Brokers want to attract listings, 
and the likelihood of obtaining a listing is correlated with the asking prices posted. Also, sellers see the worth of their properties as embodied in the 'comparable' sales at their peak: 'Sarah sold her house next door for $\$ 455,000$ two years ago, and my house is identical except for the new kitchen I added. Mine must be worth at least as much as hers.'

Anyone who has ever participated in the housing market knows that the clearing process is far from the traditional Marshallian auction. Without doubt, if all the houses for sale on a given day were auctioned by sunset the next day, housing prices would be less stable. But sellers hold out in a great many instances, refusing to lower their asking prices for some fairly prolonged period. This behavior has been rationalized by Genesove and Mayer (2001).

Figure 1 indicates what happens in a typical demand-driven downturn. First, demand drops (from D to $\mathrm{D}^{\prime}$ ) as buyers stop looking and stop making offers. Sellers, on the other hand, hold out at the 'sticky price.' That increases the spread between bid and asked prices, and agreements are not reached. The result is a sharp drop in the number of units sold each period and an interval in which observed prices are simply flat. Notice that appraisers and listing agents still observe transactions at the sticky price, and must interpret them as 'the market price.' However, these prices are no longer the prices that clear the market. These latter prices are not observed but can only be inferred.

Case and Shiller $(1988,2003)$ have surveyed home buyers for nearly two decades, and consistent evidence of this stickiness is found in buyers' responses to survey

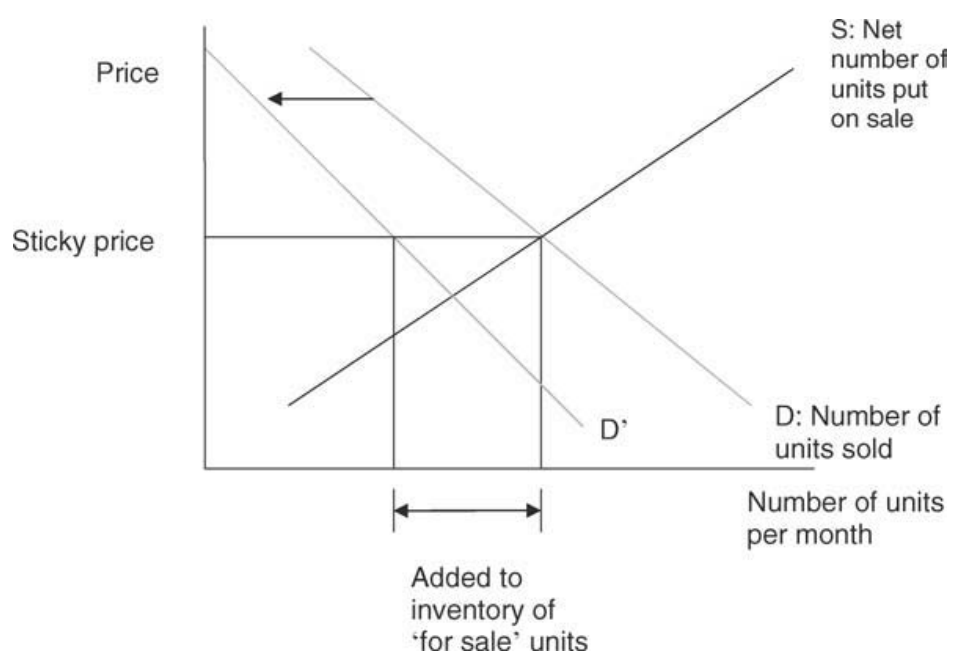

Figure 1. The housing market. 
questions. Households who sold properties prior to buying in four US metropolitan areas (Orange County and San Francisco in California, Boston, and Milwaukee) were asked, 'If you had been unable to sell your home for the price that you received, what would you have done?' The answers of the 254 respondents in the first survey have not materially changed over the years. Of the total, 37 per cent said that they would have 'left the price the same and waited for a buyer, knowing full well that it might take a long time.' Another 28 per cent answered that they would have taken the house off the market or rented it. In addition, 30 per cent answered that they would have 'lowered the price step by step hoping to find a buyer.' Only 12 respondents, less than 5 per cent, answered that they would have 'lowered the price until they found a buyer.'

Contemporaneous evidence on the downward stickiness of prices at the beginning of a downturn can be found in a stratified random sample of 628 houses that were listed by a major Boston multiple listing service in July 2006. Table 1 shows the

Table 1. Disposition of Houses Listed for Sale in July 2006, as of November 2006 Suburban Boston MLS Listings (628 Observations)

\begin{tabular}{|c|c|c|c|c|c|c|c|c|}
\hline \multirow[b]{3}{*}{ Town } & \multirow{2}{*}{\multicolumn{5}{|c|}{ Disposition of Listing }} & & \multicolumn{2}{|c|}{ Percent Decrease } \\
\hline & & & & & & & \multirow{2}{*}{$\begin{array}{l}\text { in Asking } \\
\text { Price }\end{array}$} & \multirow{2}{*}{$\begin{array}{l}\text { Selling } \\
\text { Price }\end{array}$} \\
\hline & Active & Expired & Cancelled & Pending & Sold & & & \\
\hline Acton & 17 & 3 & 2 & 2 & 6 & & 4.0 & 5.4 \\
\hline Andover & 10 & 5 & 6 & 2 & 7 & & 4.0 & 4.7 \\
\hline Braintree & 11 & 8 & 3 & 2 & 6 & & 4.2 & 5.4 \\
\hline Concord & 13 & 5 & 4 & 1 & 7 & & 5.9 & 11.1 \\
\hline Essex & 9 & 7 & 2 & 5 & 5 & & 6.1 & 6.4 \\
\hline Foxboro & 10 & 1 & 8 & 0 & 11 & & 4.9 & 7.4 \\
\hline Hamilton & 10 & 8 & 3 & 4 & 5 & & 4.9 & 9.3 \\
\hline Hull & 9 & 6 & 4 & 2 & 9 & & 5.5 & 5.4 \\
\hline Ipswich & 10 & 10 & 4 & 1 & 5 & & 3.2 & 3.4 \\
\hline Lexington & 10 & 5 & 4 & 4 & 7 & & 4.7 & 6.0 \\
\hline Needham & 12 & 3 & 10 & 3 & 2 & & 4.9 & 3.9 \\
\hline Quincy & 9 & 8 & 5 & 3 & 5 & & 4.6 & 10.6 \\
\hline Reading & 5 & 8 & 4 & 5 & 8 & & 5.9 & 7.2 \\
\hline Sharon & 7 & 10 & 3 & 2 & 8 & & 3.0 & 5.8 \\
\hline Stoneham & 7 & 7 & 3 & 4 & 9 & & 4.3 & 6.2 \\
\hline Wakefield & 9 & 7 & 1 & 1 & 12 & & 4.8 & 4.0 \\
\hline Walpole & 6 & 6 & 6 & 4 & 8 & & 4.0 & 7.3 \\
\hline Wayland & 10 & 8 & 4 & 3 & 5 & & 4.0 & 4.7 \\
\hline Wellesley & 15 & 3 & 4 & 4 & 4 & & 1.9 & 7.0 \\
\hline Weymouth & 14 & 3 & 6 & 0 & 7 & & 3.8 & 4.5 \\
\hline Winchester & 10 & 12 & 4 & 0 & 4 & & 2.5 & 5.9 \\
\hline $\begin{array}{l}\text { Listing } \\
\text { Totals }\end{array}$ & 213 & 133 & 90 & 52 & 140 & $\begin{array}{l}\text { Average } \\
\text { Decreases }\end{array}$ & 4.3 & 6.3 \\
\hline
\end{tabular}

Note: All towns have sample size of 30, except for Essex (28 observations). 
disposition of those properties in December, five months later. Of the 628 properties listed, 436 (nearly 70 per cent) had not been sold. Their listings are described as 'expired,' 'cancelled,' or still 'active.' Of the remaining July listings, only 192 were under agreement or had been sold by December 2006. Despite the fact that these unsold properties are expanding the inventory available, their impact on prices seems to be modest. The mean decline in asking price from the price the time of original listing was 4.3 per cent. For properties that had actually sold, the mean price decline since first listing ranged from 3.4 per cent in Ipswich to 11.1 per cent in Concord. The average price decline was about 6.3 per cent.

Downward stickiness is most evident when demand declines are triggered by increases in mortgage interest rates. A classic example was observed at the end of the first California boom, which lasted from mid-1975 to the third quarter of 1980. During this period, house prices in the state nearly tripled, increasing 170 per cent. But in 1980 , mortgage interest rates increased steeply, to as much as 18 per cent. A national recession itself dampened demand in the state, but the combination of high interest rates and the recession caused the housing market to contract sharply. Despite these factors, average house prices in California never fell in the ensuing period. Rather, average house prices and house price indexes were simply flat in nominal terms for four years from the third quarter of 1980 .

The fact that, in 1981, the US mortgage market was completely dominated by 30 -year fixed-rate self-amortizing mortgages added to the stickiness of prices. Those home owners who contemplated selling as rates rose found themselves facing enforceable due-on-sale clauses. Most potential sellers had long-term mortgages at low interest rates. With interest rates at the time above 15 per cent, most sellers were required to liquidate cheap fixed-rate loans at par. The importance of the fixed-rate mortgage in maintaining sticky prices can be inferred by observing the Canadian market. In Canada, the UK, and in most of continental Europe as well, the mortgage market is dominated by adjustable rate mortgages; in Canada many had no caps. Thus, when interest rates rose, homeowners faced dramatically higher payments, and many had to sell or face default. Figure 2 compares the course of home prices measured by repeat sales indexes in Vancouver and San Francisco between 1975 and 1983. Between 1975 and 1981, nominal home prices increased 154 per cent in San Francisco and 214 per cent in Vancouver. Thereafter, both Pacific Coast cities experienced rapidly rising interest rates and a recession. San Francisco saw practically no decline in prices. As noted above, prices in San Francisco stayed flat in nominal terms for 16 quarters until they resumed their rise in the second quarter of 1984. In sharp contrast, Vancouver saw a sharp price drop of over 35 per cent within a period of seven quarters.

While prices held firm, San Francisco experienced a very sharp decrease in the volume of sales. Sales of existing homes fell by more than half. Housing starts for the Western Census region peaked in September 1979 at 645,000, and they fell by 77 per cent to a low of 148,000 in February 1982. 


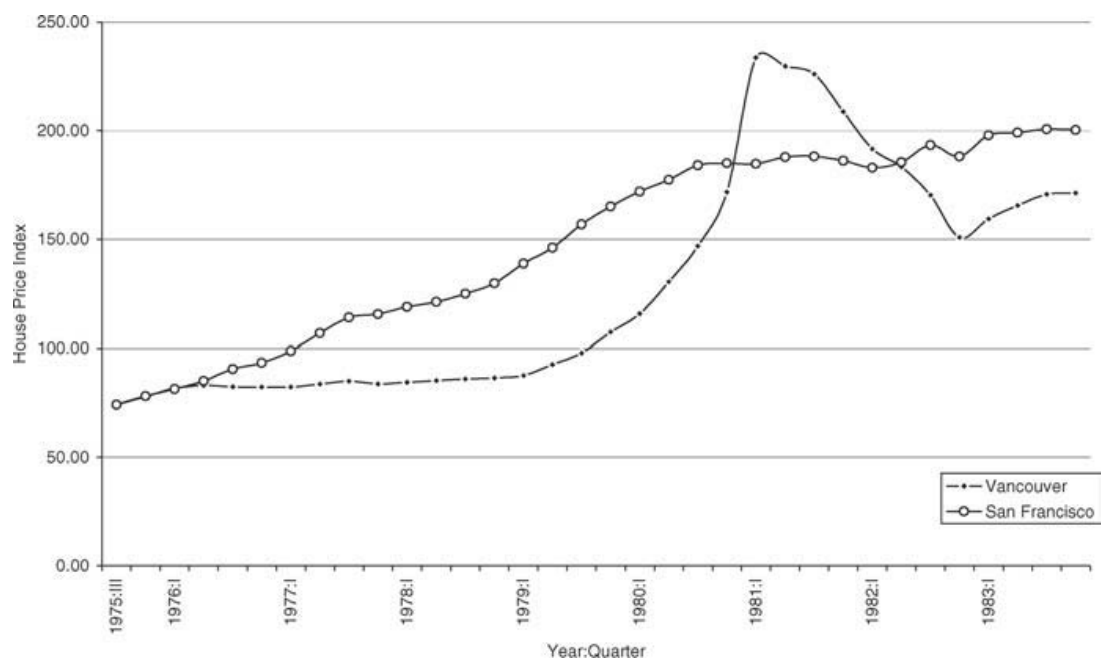

Figure 2. Nominal House Prices in Vancouver and San Francisco: 1975-1983.

It is clear that downwardly sticky house prices accompany almost every major regional slow down in the housing market. The extent of this resistant behavior ultimately affects the relative size of the income effect, the wealth effect, and the degree of financial market dislocation that is likely to result from the slow down. Table 2 provides data on the actual decline in house prices since the US housing market peaked between late 2005 and mid 2006. The data are based on deed recordings of arms length sales through the end of 2007. As of December, a price decline was apparent in all of the 20 metropolitan areas tracked by the S\&P Case Shiller Indexes (standardandpoors.com). The average decline across these large metropolitan areas was 10.5 per cent from peak; but since 2000 prices in those 20 cities have still doubled. If the value of the entire housing stock actually declined by 15 per cent, aggregate housing wealth would have fallen by $\$ 3$ trillion. Further, if the wealth effect were symmetric, the implied elasticity from Case et al. (2005) suggests a wealth effect of $\$ 105$ billion. As discussed below, this is significant, but modest relative to the potential income effects and financial market effects.

While the house price decline continues and some expect really large declines in house prices (Shiller, 2007), 15 per cent seems a likely upper found. If housing wealth has an asymmetric effect on spending, the wealth effect, of course, would be less than $\$ 100$ billion or less than 1 per cent of GDP.

\section{Income Effects}

The magnitude of the income effect from a housing downturn depends on several factors. First, the direct impact of a slowdown in residential fixed investment affects 
Table 2. House price changes in 20 US Metropolitan Areas, 2000-2007*

\begin{tabular}{lccc}
\hline $\begin{array}{c}\text { A. Metropolitan areas } \\
\text { with falling prices }\end{array}$ & $\begin{array}{c}\text { Per cent change } \\
\text { since January } \\
2000\end{array}$ & $\begin{array}{c}\text { Peak } \\
\text { month }\end{array}$ & $\begin{array}{c}\text { Per cent } \\
\text { decline since } \\
\text { the peak }\end{array}$ \\
\hline $\begin{array}{l}\text { Detroit } \\
\text { Tampa }\end{array}$ & +10 & $12 / 05$ & -13.8 \\
San Diego & +119 & $7 / 06$ & -7.9 \\
Washington, DC & +131 & $11 / 05$ & -7.6 \\
Boston** & +133 & $5 / 06$ & -7.0 \\
Philadelphia & +71 & $10 / 05$ & -6.1 \\
Las Vegas & +113 & $7 / 06$ & -6.5 \\
Miami & +109 & $8 / 06$ & -5.5 \\
Los Angeles & +165 & $5 / 06$ & -4.9 \\
San Francisco & +162 & $7 / 06$ & -4.8 \\
Minneapolis & +109 & $5 / 06$ & -4.1 \\
Cleveland & +64 & $10 / 06$ & -4.0 \\
New York & +19 & $8 / 05$ & -3.8 \\
Denver & +109 & $5 / 06$ & -3.4 \\
Chicago & +38 & $8 / 06$ & -1.6 \\
\hline B. Metropolitan areas & +66 & $10 / 06$ & -1.6 \\
$\quad$ with rising prices & & & Per cent change \\
\hline Seattle & & since June 2006 \\
Charlotte & +92 & & +7.9 \\
Portland & +35 & & +6.8 \\
Dallas & +85 & & +4.5 \\
Atlanta & +27 & & +1.6 \\
C. Average, all 20 cities & +36 & & -3.6 \\
\hline & +100 & & \\
\hline & & & \\
(10) & & & \\
\hline
\end{tabular}

${ }^{*}$ Changes in S\&P Case-Shiller metropolitan price indexes.

** Boston began to fall in October 2005, stopped falling in February 2007 (down 7.9 per cent), and then rose between February and June 2007 by 1.9 per cent.

developers, builders, and the construction industry. Second, a decline in sales of existing homes reduces the incomes of brokers, mortgage originators, lenders, and others involved in the process. The drop in residential investment is likely to be much larger since a new house is generally produced in the nine to twelve month period before it is offered for sale. In contrast, the sale of an existing home represents an asset transfer, not new output.

While this asset transfer will generate fees and increased income, the total is only a small fraction of the value of the asset.

Finally, there is a multiplier. The multiplier on fixed investment spending has been estimated to be about 1.4 (implicit in the Fair Model, discussed below), although the actual effect will depend on the behavior of the rest of the economy. Roughly speaking, a 100 dollar drop in income from a decline in residential investment will reduce national income by about 140 dollars. 
One way to gauge the magnitude of these effects in the US today is to compare the performance of housing investment and new home construction during past cycles. Figure 3 reports monthly housing starts between January 1972 and December 2007. Figure 4 indicates the pattern of real gross residential investment from the Bureau of Economic Analysis for the same period

During the 35 year period reported in these figures, four significant declines are evident; we refer to these as Cycles I-IV below. The first three all contributed to recessions. The first was during the stagflation period leading up to the US recession of 1975. The second was a long decline beginning in 1978 leading up to the recession of 1981-1982. The third occurred as severe regional recessions led to a national recession in 1990. The fourth began in early 2006 and continues through June 2008.

It is important to note that each of the first three down cycles arose, in some measure, in response to Federal Reserve interest rate policies to reduce inflationary pressures. In all three cases, but especially in 1974-1975 and in 1980-1982, interest rates rose substantially. Interest rates in the current downturn have risen only modestly, and were reduced by the actions of Federal Reserve Open Market Committee in September 2007.

Table 3 reports the magnitude of each the four down cycles, measured by residential investment and housing starts. Note that housing starts are a leading indicator of gross investment. A 'star' is recorded when investment in a new home begins. The investment itself continues for a period of up to a year. Note the lags involved. To illustrate, the Census Bureau reported in October 2006, that new house completions were at an annual rate of 2 million, despite the fact that housing starts had fallen well below 2 million in March and had fallen steadily through October, to a rate below 1.5 million (see US Bureau of the Census, New Residential Construction, October 2006).

Cycle I began with a downturn in both housing starts and residential investment. In the first quarter of 1973, housing starts were at an annual rate of 2.48 million the highest level recorded for any month between 1959 and 2007. Interestingly, in January 2006, annual starts were estimated to be 2.27 million - the highest figure recorded for any month since April 1973. The drop in starts during Cycle I bottomed at a rate of 904,000 in February 1975. The decline lasted two years, during which housing starts fell by 1.58 million units or 63 per cent.

During this cycle, the pattern of real gross residential investment lagged starts, but only modestly. Real residential fixed investment peaked in the first quarter of 1973 at $\$ 310.6$ billion and then fell to $\$ 189.2$ billion, a decline of 39 per cent. As a per cent of GDP, gross residential investment fell from 5.7 per cent to 3.6 per cent. In many respects, Cycle II was similar to Cycle I. The expansion following the end of the recession in 1975 began to engender inflation in 1977. The Federal Reserve increased interest rates in 1978 in anticipation of an acceleration of inflation, and the housing 


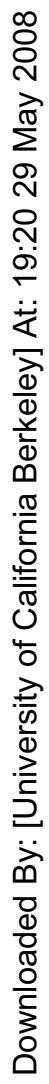

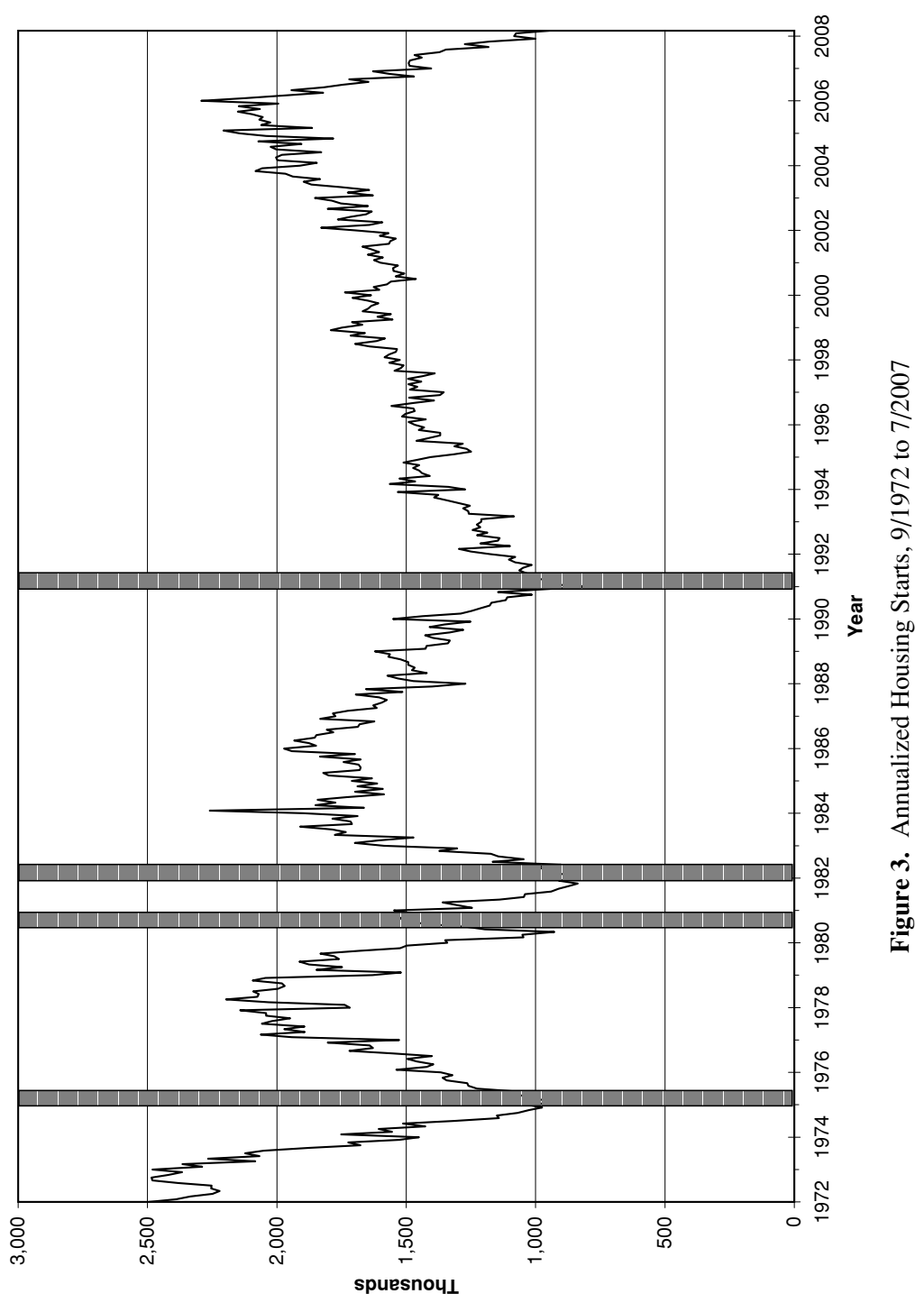




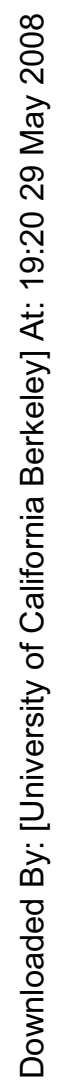

172 K.E. Case \& J.M. Quigley

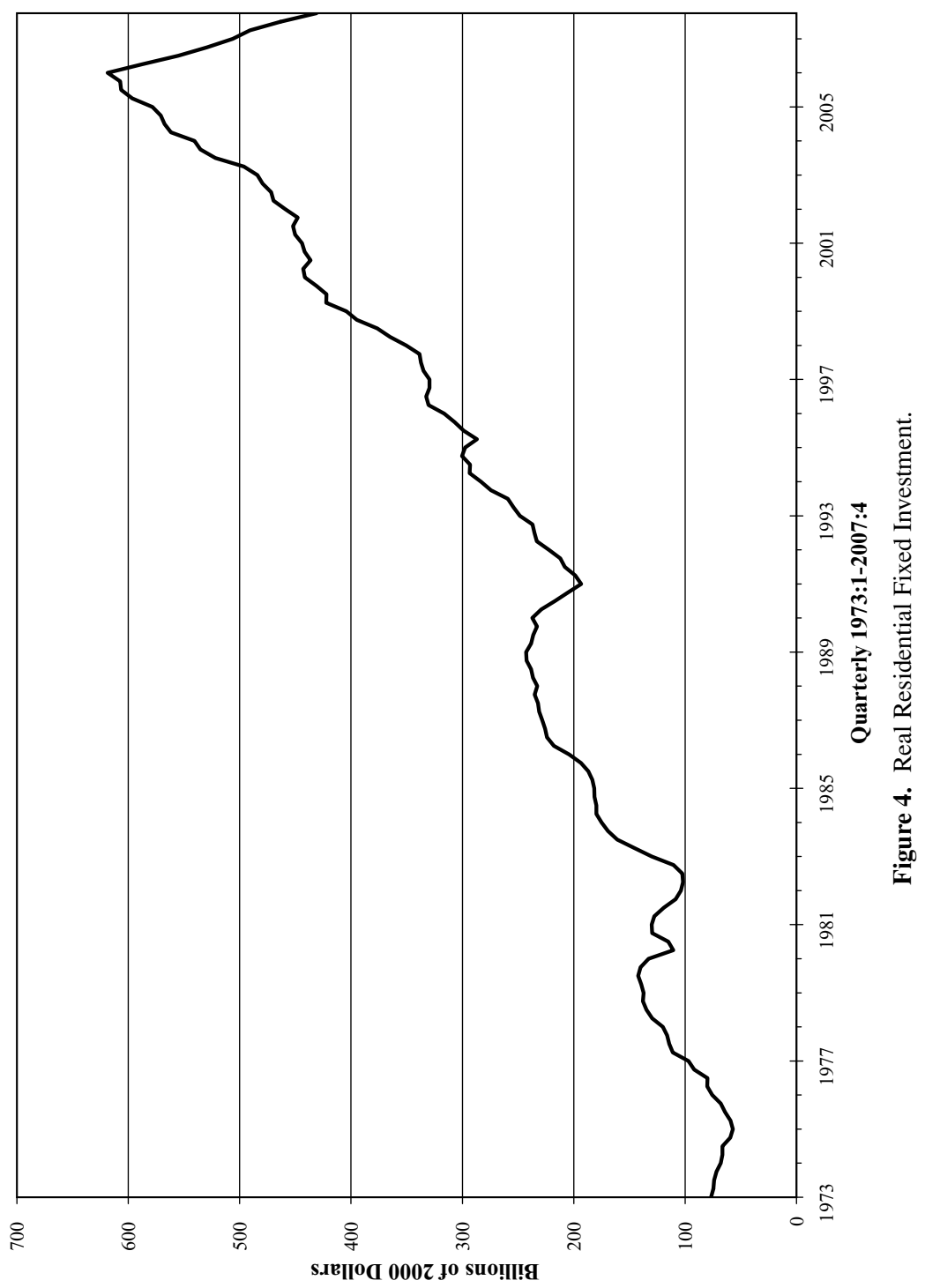


Table 3. Gross Residential Investment and Housing Starts in Down Cycles, 1973-2008

\begin{tabular}{lccc}
\hline Cycle I* & Peak 1973:1 & Trough 1975:1 & Percent Change \\
\hline $\begin{array}{l}\text { Gross Residential Investment } \\
\text { (billions of } \text { ) }\end{array}$ & $\$ 310.6$ & $\$ 189.2$ & -39 \\
$\begin{array}{l}\text { Percent of GDP } \\
\text { Housing Starts (millions of units) }\end{array}$ & 2.481 & 3.6 & -63 \\
\hline Cycle II* & Peak 1978:3 & Trough 1982:3 & Percent Change \\
\hline $\begin{array}{l}\text { Gross Residential Investment } \\
\text { (billions of \$) }\end{array}$ & $\$ 356.6$ & $\$ 182.9$ & -49 \\
$\begin{array}{l}\text { Percent of GDP } \\
\text { Housing Starts (millions of units) }\end{array}$ & 2.141 & 3.5 & -61 \\
\hline $\begin{array}{l}\text { Cycle III* } \\
\text { Gross Residential Investment } \\
\text { (billions of \$) }\end{array}$ & Peak 1986:4 & Trough 1991:1 & Percent Change \\
$\begin{array}{l}\text { Percent of GDP } \\
\text { Housing Starts (millions of units) }\end{array}$ & 2.260 & $\$ 250.0$ & -30 \\
\hline $\begin{array}{l}\text { Cycle IV* } \\
\text { Gross Residential Investment } \\
\text { (billions of \$) }\end{array}$ & $\$ 607.2$ & 3.5 & -65 \\
$\begin{array}{l}\text { Percent of GDP } \\
\text { Housing Starts (millions of units) }\end{array}$ & 2.265 & $\$ 430.9$ & -29 \\
\hline
\end{tabular}

*Peak and trough dates are for gross residential investment. For housing starts, peak and trough dates are: Cycle I: January 1973 - February 1975.

Cycle II: December 1977 - August 1981.

Cycle III: February 1984 - January 1991.

Cycle IV: January 2006 - March 2008.

Source: US Bureau of the Census, Construction Reports; Board of Governors of the Federal Reserve System, Flow of Funds Data, Table F10, Line 19 and Bureau of Economic Analysis, Gross Domestic Product release March 27, 2008, Table 1.1.6.

market began to cool. Housing starts began to decline in January 1978. From a peak of 2.14 million at the end of 1977 , the number fell to 927,000 over the next three years.

Real gross fixed residential investment fell, this time from $\$ 356.6$ billion in 1977 to $\$ 182.9$ billion, a decline of almost half over a four-year period. As a percentage of GDP, residential investment dropped from 5.5 per cent in 1978 to 3.5 per cent at the end of 1982.

The relative magnitudes of the Cycle III downturn are clearly apparent in Table 2. The decline in housing starts occurred in February 1984, long before a recession was eminent. Starts dropped again from 2.26 million to a bottom below 798,000 in January 1991, a decline of over 65 per cent. 


\section{K.E. Case \& J.M. Quigley}

This time there was a considerable lag between the decline in housing starts and the ultimate reduction in real residential fixed investment, which began in the fourth quarter of 1986. In Cycle III, the decline was only 30 per cent. Interestingly, the peak of residential fixed investment in real terms in 1986 was identical to the peak for residential fixed investment in 1978. Both were just 18 per cent above the peak level in 1973. From the peak, residential fixed investment fell from $\$ 356$ billion, or 5.6 per cent of GDP, to $\$ 250$ billion, or 3.5 per cent of GDP in January of 1991.

The three previous downturns had some striking similarities despite rather different economic circumstances. In all three cases, housing starts fell by about $60-65$ per cent, while gross residential investment fell from about 5.5 per cent to about 3.5 per cent of GDP.

The current downturn appears to be different in some dimensions and similar in others. First, the peak in starts was again over 2 million. This time, however, gross residential investment in real dollars at the peak was significantly higher than it had been during the last three peaks. This is clearly visible in Figure 4. However, the peak, as a percentage of GDP was 5.5 per cent, exactly what it had been in the previous downturns. Clearly the housing decline will be a drag on the US economy throughout 2007 and 2008. But how much of a drag?

Housing starts were down to 947,000 by March 2008, a decline of 1.3 million units at annual rates. At a mean price of $\$ 300,800$, this would have represented a decline in final demand of roughly $\$ 189,504$ per unit net of land and imports (i.e. 63 per cent of $\$ 300,800)$, or $\$ 250$ billion.

Thus, ignoring any decline in the sales of existing homes, the decline in housing starts which was observed in the first half of 2007 reduced the GDP growth rate in 2007 by about 2 per cent.

This ignores the multiplier, and it leaves residential fixed investment at about 4.3 per cent of GDP. If we assume instead that residential fixed investment will fall to 3.5 per cent of GDP, the historic trough, residential investment will fall by more than $\$ 100$ billion in nominal terms by 2008 . This figure implies housing starts of roughly 850-900,000, consistent with past troughs.

Other direct effects on income from this decline include loss of brokerage commissions, fees from mortgage originations, and those services which are reckoned as 'closing costs' (including appraisal fees, building inspections, title insurance, and so forth). Existing home sales were lower by 2 million in March 2008 from their level at the end of 2005, and they are likely to decline further. The decline through March meant a loss of brokerage fees of almost $\$ 20$ billion. (This assumes average sales prices of $\$ 250,000$, an average commission of 5.5 per cent, and that 70 per cent of sales include brokers' participation.) Closing costs currently average about $\$ 1,700$ per sale. With 1.5 million sales, this represents $\$ 2.6$ billion in lost income. A reasonable decline in mortgage originations would be an additional $\$ 1$ million. Those mortgages would have generated about 300 basis points in total fees at origination. If the mean mortgage amount were $\$ 200,000$, then a total of about $\$ 8$ billion in fee income would 
be lost. Together, these three items yield a total of $\$ 32$ billion in lost income. Adding this to the potential loss of new construction, the total decline now appears to be about 3 per cent of GDP.

\section{Some Simulations}

To estimate the magnitude of the impacts of a downturn in housing production on the US national economy, we simulated the effects of a substantial decline in housing investment on real GDP using the well-known Fair Model of the economy (see Fair, 2004). This model, consisting of 30 stochastic equations and about 100 identities, has been used extensively in evaluating potential economic shocks and policy options for over three decades. The track record of the model is reported in Fair (2004).

The latest forecast available utilizes data through the fourth quarter of 2007 . We conduct a simulation based on an assumed exogenous decline in real gross residential investment. Recall that during the three previous housing downturns, real gross residential investment fell by between 30 and 50 per cent; this was, on average, about approximately 2 per cent of GDP. The simulation exercise, reported in Figure 5, contemplates a decline in residential investment of $\$ 275$ billion, starting at the peak of $\$ 525$ billion in 2005:IV, and bottoming out at $\$ 250$ billion in 2008:IV. A rebound begins in 2009:I. Of this simulated decline, a drop of $\$ 155$ billion in residential

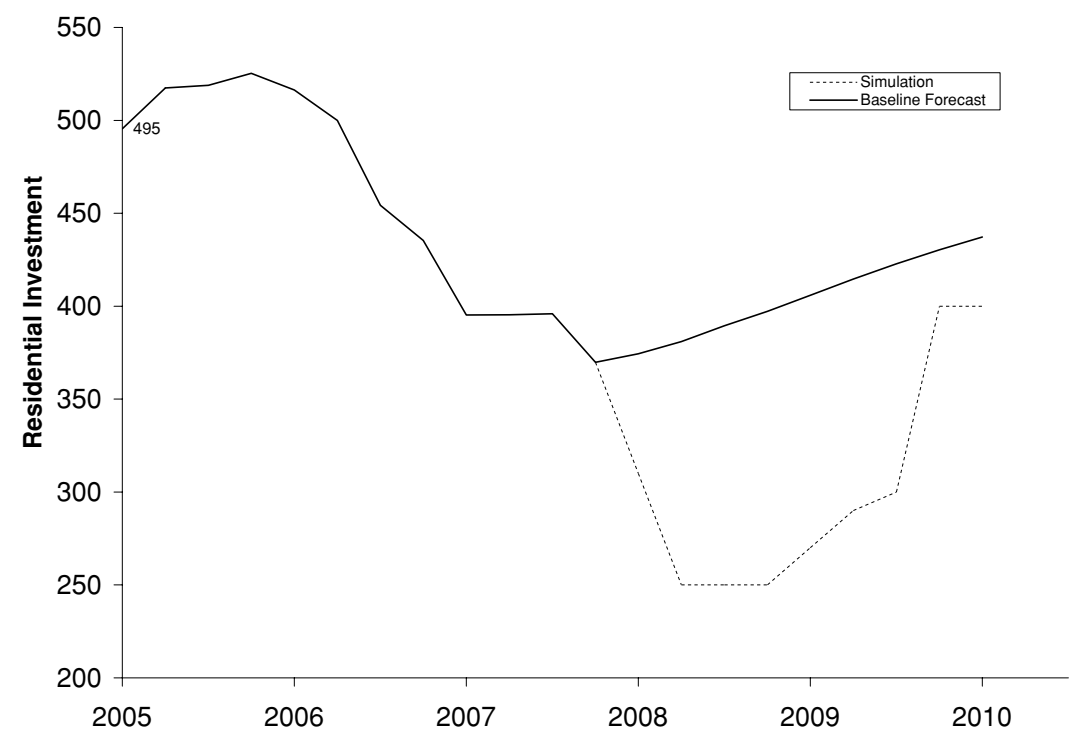

Figure 5. Real Residential Investment, Annualized (Billions of 2000 Dollars). Source: Fair Model simulation using data through 2007:IV. 
investment had already been observed by 2007:IV. That leaves $\$ 120$ billion to be experienced between 2007:IV and 2008:IV. This is fully consistent with the sharp decline in housing starts observed in the spring of 2008.

The baseline simulation does not actually predict a recession for the US economy. The real growth rate reached a low of 0.6 percent in 2007:IV, and the baseline simulation forecasts short-term growth to be 2.5 percent or more. This is based upon the observed decline in real residential fixed investment of about one quarter from 2005:IV and a projected recovery in the first quarter of 2009.

The simulation reported in Figure 5 and in Table 4 is based on a decline in residential investment of about 50 percent from its peak to 2008:IV and a slower recovery beginning in the first quarter of 2009. As indicated in Table 4, with the larger decline in residential investment, real growth declines to 0.6 percent in 2008:II and remains below the growth rate of the baseline forecast until 2009. The impact on employment is quite large. Total payroll jobs are reduced by 870,000 from the baseline in the first quarter of 2009, and the difference remains above 300,000 in 2010. Under the more pessimistic simulation, the unemployment rate peaks at 5.6 percent in early 2009, while the baseline simulation forecasts a peak unemployment rate fully one half percent less.

The simulation suggests that the likely path of residential fixed investment will push the US economy to the very brink of a recession in the short term. But of course, these projections completely ignore any effects of the housing collapse transmitted through financial markets. These mechanisms, discussed below, have been increasingly important since the summer of 2007, suggesting that a recession arising from the housing downturn in the US economy is highly probable.

\section{Financial Market Effects}

During the summer of 2007, liquidity in financial markets evaporated due to rapidly rising default and foreclosure rates, particularly in the sub-prime, Alt A, and the resetting ARM markets, many of which also carried teaser rates. For most of the past two decades, a highly competitive, innovative and liquid market had made mortgage money available to households who would not have met previous underwriting standards. With housing prices rising in most of the country, the increased collateral kept default rates, and certainly foreclosure rates, low.

A good deal of evidence suggests that default and foreclosure rates do not rise significantly unless property values fall (see Case \& Shiller, 1996). The declines in value discussed above appear to be the proximate cause of the sub-prime crises. But with property values falling and monthly payments about to be re-set, a great deal of uncertainty is priced into the market. This uncertainty has caused a rapid, unanticipated, and extensive decline in liquidity. Much of the outstanding sub-prime paper is held as whole loans or as low-grade MBS by sub-prime companies, buy-andhold mortgage companies (e.g. Countrywide in the US), pension funds, insurance companies, and worldwide investors. Much of this debt was leveraged. As the quality 


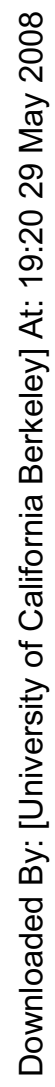

How Housing Booms Unwind 177

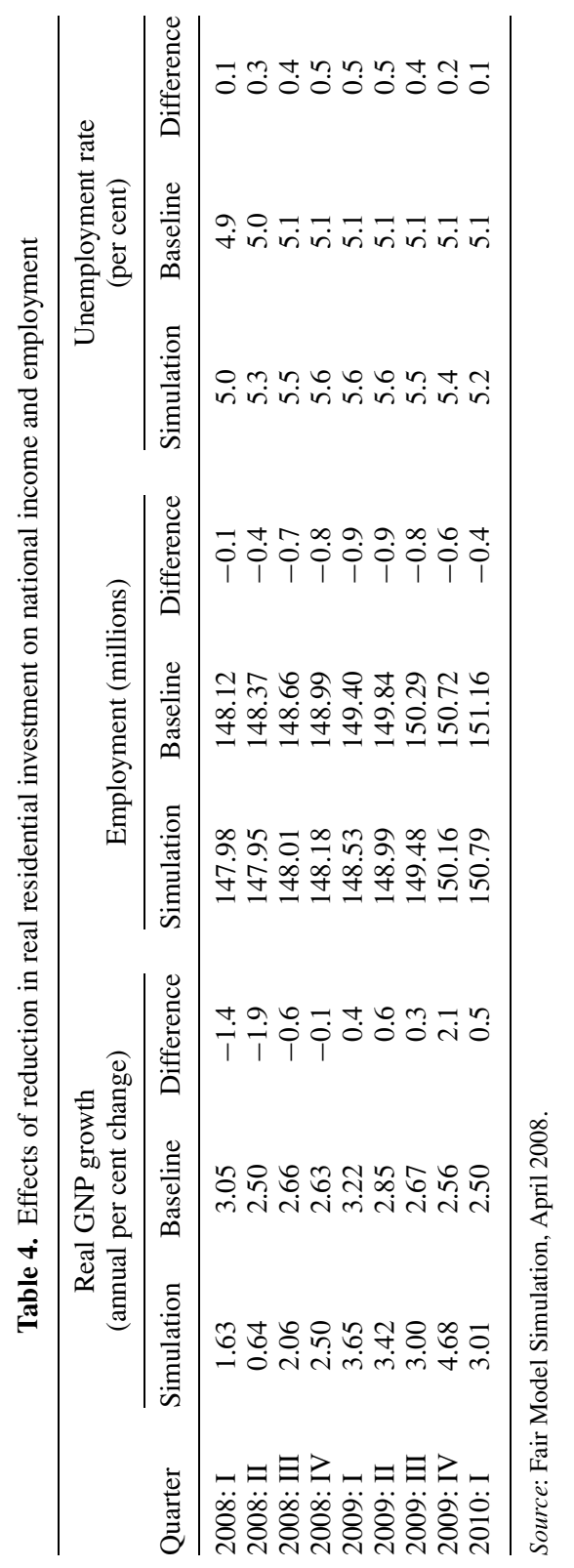


of the underlying credit, as evidenced by default rates, has fallen, buyers have simply disappeared. At the same time, nervous banks and Wall Street firms have been calling outstanding loans, even when lenders have reasonable expectations of being paid off in full. Many banks became much more aggressive, seizing collateral for quick resale, often realizing substantial losses. There was little demand for anything but the highest quality debt after June 2007. Many highly profitable companies were threatened with bankruptcy because they didn't have the ability to generate cash quickly - even though the cash flows from their bond portfolios remain quite sound.

What is the effect of this unprecedented mortgage crisis on the US economy?

Some evidence is available. Since the summer of 2007, the Federal Home Loan Banking system has greatly increased lending to member banks. (These mechanisms for stimulating retail lending are described in Green \& Wachter, 2007.) Despite this, a sharp drop in pending home sales was reported by the National Association of Realtors in September 2007, and this continues through June 2008. The cause of this decline seems to have been a dramatic change in mortgage underwriting standards. This has increased denial rates by lenders for loans which have always been profitable to them. By September, the demand for mortgages in the sub-prime sector of the market as well as the jumbo sector dried up completely. The supply of credit had evaporated.

There is further evidence on the losses from payment resets - increases in payments on adjustable mortgages arising from contractual terms and expired teaser rates. In March 2007, First American Core Logic forecasted losses at \$112 billion over five years from 1.1 million foreclosures (Cagan, 2007). When compared to the $\$ 2$ trillion in loan originations as recently as 2004 , these losses seem manageable. Data released by Loan Performance, Inc suggests that the problem is larger (http://www.loanperformance.com). By including all mortgage loans - sub-prime (B\&C, Alt A, no-doc) pools, home improvement loans, high LTV loans (over 125 per cent), home equity lines (HELOCs) and second mortgages - they calculate loss exposure at 8.8 million loans, totaling nearly $\$ 2$ trillion dollars.

Clearly it is impossible to tell just how large the impact of this debt/liquidity problem will be, but the industry is shedding jobs at a rate that points to sharply lower originations and a continuing credit crunch. Mortgage Daily (7 September 2007) estimated that 20,000 of 53,000 total mortgage brokerage firms will exit the industry by the summer of 2008 and another 5,000 by mid 2009. It was widely reported that Countrywide cut 26,000 jobs in September 2007. Three months later, it was acquired by Bank of America, presaging further job cuts.

As early as the Fall of 2007, reverberations from housing in US financial markets were apparent in other large markets. In the UK, a bank run on Northern Rock had precipitated direct action by the Bank of England. At the same time, the London-based HSBC announced the closure of its mortgage division, laying off 800 staff and taking a change of $\$ 945$ million against its balance sheet.

All of this has occurred in a relatively low interest rate environment and without a recession. 


\section{Conclusion}

On the current trajectory, the fading boom in the US housing market will lead to: reductions in consumer spending; declines in housing starts, completions and net residential investment; and to reductions in housing transactions volumes and the associated fee income from these activities. It will also lead to repercussions through financial markets in the US and in Europe as well. This paper provides an order-ofmagnitude estimate of these effects using the history of the past three downturns in the housing market as a backdrop. We estimate very small consequences for the economy from the wealth effect, but quite large consequences arising from the income effect associated with a decline in the housing sector.

The decline in the U.S. housing market since after 2006 had already exerted a major impact on national income by early 2008. As of March 2008, the decline in residential investment (net of imported material and not including land) was roughly $\$ 250$ billion. In addition, lost fees and mortgage business resulting from the decline in existing home sales totaled roughly $\$ 32$ billion, bringing the direct income effects to over $\$ 280$ billion. If a reasonable multiplier of 1.4 is applied to that figure, the total direct and indirect impacts of the housing market decline which had already taken place by early 2008 comes to roughly 2.9 percent of GDP each year until recovery. The US economy had been growing at about that rate; thus the housing decline by itself had brought the economy to the doorstep of recession by March 2008. During the last quarter of 2007 and the first quarter of 2008, the U.S. economy grew at a rate of about 0.6 percent.

The situation in early 2008 was very similar to conditions at the bottoms of the last three national cycles. Housing starts have now fallen for the fourth time since 1973 from over two million at the peak to under a million. In the three previous quarters (since 1973) in which housing starts have fallen below one million, the US economy has slipped into recession.

When the financial market effects are added to these direct income effects, current developments in the US housing market may lead to broader reversals, zero growth, and perhaps a recession in the US economy during 2008. These effects will be felt more broadly in European financial and product markets as well.

\section{Acknowledgments}

A previous version of this paper was presented at a joint session of the American Economic Association and the American Real Estate and Urban Economics Association, Chicago, January 5 2007. The paper benefited from the comments on Chris Mayer and from those of two anonymous referees. We are also grateful for the help of Larry Rosenthal and for the invaluable research assistance of Alexandra Toteva.

\section{References}

Abramovitz, M. (1964) Evidence of Long Swings in Construction since the Civil War (New York: National Bureau of Economic Research). 
180 K.E. Case \& J.M. Quigley

Blank, D. M. (1954) The Volume of Residential Construction, 1889-1950 (New York: National Bureau of Economic Research).

Cagan, C. L. (2007) Mortgage Prepayment Reset (Sacramento, CA: First American Core Logic).

Case, K. E. (1986) The market for single family homes in Boston, 19791985, New England Economic Review, May/June.

Case, K. E. (2007) The value of land in the United States: 1975-2005, in Gregory K. Ingram and Yu-Hung Hong, eds., Land Prices and their Outcomes (Cambridge, MA: Lincoln Institute of Land Policy), pp. 127-146.

Case, K. E., Quigley, J. M. \& Shiller, R. J. (2005) Comparing wealth effects: the stock market versus the housing market, Advances in Macroeconomics, 5(1), pp. 1-32.

Case, K. E. \& Shiller R. J. (1988) The behavior of home buyers in boom and post boom markets, New England Economic Review, November/December, pp. 29-46.

Case, K. E. \& Shiller, R. J. (2003) Is there a bubble in the housing market?, Brookings Papers on Economic Activity, 2, pp. 299-362.

Fair, R. C. (2004) Estimating How the Macroeconomy Works (Cambridge, MA: Harvard University Press). Genesove, D. \& Mayer, C. J. (2001) Loss aversion and seller behavior: evidence from the housing market, Quarterly Journal of Economics, 80(2), pp. 287-312.

Green, R. K. \& Wachter, S. N. (2007) The housing finance revolution, paper prepared for the conference on housing, housing finance, and monetary policy, sponsored by the Federal Reserve Bank of Kansas City, Jackson Hole, WY, September.

Jaffee, D. \& Quigley, J. M. (2007) Housing policy, subprime mortgage policy, and the federal housing administration, Berkeley program on housing and urban policy, Working Paper W07-004, August.

Leamer, E. E. (2007) Housing is the business cycle, paper prepared for the conference on housing, housing finance, and monetary policy, sponsored by the Federal Reserve Bank of Kansas City, Jackson Hole, WY, September.

Muellbauer, J. N. (2007) Housing, credit and consumer expenditure, paper prepared for the conference on housing, housing finance, and monetary policy, sponsored by the Federal Reserve Bank of Kansas City, Jackson Hole, WY, September.

Shiller, R. J. (2007) Understanding recent trends in house prices and homeownership, paper prepared for the conference on housing, housing finance, and monetary policy, sponsored by the Federal Reserve Bank of Kansas City, Jackson Hole, WY, September.

Wickens, D. L. \& Foster, R. R. (1937) Non Farm Residential Construction (New York: National Bureau of Economic Research).

Zarnowitz, V. (1992) Business Cycles: Theory, History, Indicators, and Forecasting (New York: National Bureau of Economic Research). 